\title{
Shareholding Reform of State-Owned Enterprises and Control
}

\author{
(C) Higher Education Press and Springer-Verlag 2010
}

\begin{abstract}
One of the most commonly used ways to restructure big and medium-sized state-owned enterprises (SOEs) in China is through shareholding reform. This article classifies the shareholding reform into four modes and explores the relationship among these modes, in terms of the degree of control over controlled listed companies and governance efficiency. Using data of 285 SOEs during 1997-2000 (three years after their IPO), we find that restructuring modes affect the degree of control by controlling shareholders over listed companies. Furthermore, the controlling shareholder of incompletely restructured enterprises prefers a higher degree of control. In addition, the higher the degree of control, the more serious the problems of related trading and tunneling behaviors. We also find that restructuring modes affect the governance structure of listed companies, which in turn affect the degree of related trading and tunneling behaviors. These findings reveal that incomplete restructuring of SOEs before their listing is likely to make these enterprises be vulnerable to external control and thus negatively affects their governance efficiency.
\end{abstract}

Translated from Nankai Guanli Pinglun 南开管理评论 (Nankai Business Review), 2008, 11(2): 4-14

Jianping Deng $(\bowtie)$

Xiamen National Accounting Institute, Xiamen 361000, China

E-mail: djp1406@163.com

Yong Zeng

School of Management, University of Electronic Science and Technology of China, Chengdu 610054, China

E-mail: zengy@uestc.edu.cn

Jia $\mathrm{He}$

Department of Financial Accounting, The Chinese University of Hong Kong, Hong Kong, China

E-mail: hejia@baf.msmail.cuhk.edu.hk 
Keywords state-owned enterprises, shareholding reform, control

\section{Introduction}

Shareholding reform has been widely used by many transitional economies as a main method to restructure their large and medium-sized SOEs. In most cases, SOEs are transferred to legal or natural persons to ensure the separation of ownership and management, thus turning SOEs into companies with limited liabilities. In other cases, by selling part of state-owned assets or issuing new shares, many former SOEs are turned into joint-stock companies with state as a shareholder or controlling shareholder (Tian, 2002). Different from China's incremental approach to SOE reform, Russia and some eastern European countries adopted the radical approach (the so-called shock treatment), which led to serious problems of insider control. Most of these insider controllers were former managers or employees in reformed SOEs, who grabbed a large amount of control right over these enterprises during reform and used this right to their own interests (Masahiko, 1994). For example, Frydman, Pistor and Rapaczynski (1996) found that, during the privatization of Russian enterprises, although most voucher privatization funds (VPFs) attempted to get their voice heard on the board of directors, insiders on the board counterbalanced their efforts. Consequently, many VPFs chose to leave these boards. Frydman et al. argued that insider control is the greatest barrier to efficiency improvement of privatized enterprises. However, Masahiko (1994) found that employees in Polish enterprises obtained control rights after shareholding reform, but the insider control problem is less serious in the Czech Republic and Hungary. Schutte (2000) also found that most Czech citizens entrusted their shares obtained from SOE privatization reform to private investment funds, making these funds powerful and influential. In Czech, many board members are from these private investment funds. A survey conducted by Coopers and Lybrand showed that CEOs in $39 \%$ of sampled firms hold concurrently the posts of CEO and chairman of the board, $15 \%$ of sampled firms had senior managers serving as the Chairman of the board. Private investment funds appointed the chairman in about $32 \%$ the sampled enterprises. We can come to the conclusion that the management right of most of Czech enterprises is mutually shared by private investment funds and senior managers (Feng, 2003). In addition, according to Frydman et al.'s study in 1993 , only $53 \%$ of book assets of the privatized enterprises were transferred to the holder of equity warrants. Those information-possessing insiders tend to choose to purchase the enterprise themselves. Therefore, Masahiko (1994) pointed out that insider control prevails in eastern and middle European countries, varying only in degrees of seriousness.

Different from Czech, the Chinese government still holds a large part of shares of SOEs after their shareholding reforms. There are controlling shareholders in 
most of restructured listed companies. This, however, leads to another type of "insider control" problem. In other words, controlling shareholders are likely to maximize their interests at the cost of other smaller shareholders. Some of the methods that controlling shareholders might use to control listed companies include: First, to control the board of directors. Pu and Liu (2004) pointed out that, if without the ability to intervene in the board of directors, a controlling shareholder might not be able to realize his/her control over the firm, as the chairman of the board is the supreme decision-maker is the most important post in a listed enterprise (Song, 2004). Therefore, to appoint the chairman of their own is an important way for controlling shareholders to strengthen their control over listed companies. La Porta's (1999) study confirmed the above conclusion. Claessens et al. (2000) also found that in Southeast Asia, about $57.1 \%$ of family-controlled listed companies appointed members of the controlling family to the board or other senior management position. In some west European countries, this percentage reaches even as high as two thirds (Faccio, 2002). Second, to control the managerial team is another method, as it is up to the CEO to nominate, appoint or dismiss vice-chairman and the CFO, the behavior of $\mathrm{CEO}$ in a firm can decide its performance to some extent ( $\mathrm{Li}, 2005)$. Therefore, by appointing CEO of their own, controlling shareholders can strengthen their control over a listed company. Third, another approach is to control the board of supervisors. As stipulated in the new corporate law, the board of supervisors may exercise the following power: (1) to monitor the financial affairs of the company; (2) to supervise duty-related acts of the directors and senior managers, to put forward proposals on the removal of any director or senior manager who violates any law, administrative regulation, the articles of association or any resolution of the shareholders' meeting; (3) to demand any director or senior manager to make corrections if his act has injured the interests of the company; (4) to propose to call interim shareholders' meetings, to call and preside over shareholders' meetings when the board of directors does not exercise the function of calling and presiding over shareholders' meetings as prescribed in this law; and (5) to put forward proposals at shareholders' meetings. Therefore, it is rather impossible to control a firm with control its board of supervisors.

As a matter of fact, China's regulatory bodies have promulgated some clearly defined regulations to prevent cross-appointed directors from happening and to guarantee the independence of listed companies. For instance, in 1998, the China Securities Regulatory Commission (CSRC) issued the Investigation on the Restructuring of Enterprises that Propose to Issue Shares and Be Listed Circular, in which it is stipulated that, in addition to the rigorous requirements noted in the Company Law and the Provisional Regulations on the Administration of Share Issuance and Trading, enterprises must meet the following three requirements, namely personnel independence, asset completeness and financial independence. In other words, listed companies must be independent of their controlling 
shareholders in the above three perspectives. In 1999, CSRC issued the Notice on Prohibiting the CEO and Senior Manager of Listed Companies Taking Part-Time Jobs in the Enterprises of Their Controlling Shareholders, stressing again that the CEO and senior manager of listed companies shall not take posts in their controlling shareholders' company other than board directors. Three years later, CSRC issued the Code of Corporate Governance for Listed Companies in China to further emphasize the independence of listed companies. The code requires that the managers, $\mathrm{CPO}, \mathrm{CMO}$ and the secretary of the board should not take posts in their controlling shareholders' company other than board directors. Despite of CSRC's repeated objection to cross-appointed posts, however, many researchers have found that cross appointment still prevails among the senior managers of listed companies. For instance, Li (2005) found that about $94.6 \%$ of the IPO companies in 1998 had the legal representative of their controlling shareholders as their chairman or CEO, as compared with $62.6 \%$ in non-IPO companies. Consistent with this finding, Zou and Chen (2004a, 2004b) studied the data of China's listed companies in 1998-2004 and found that there were still about $60 \%$ of listed companies "share" the chairman with their controlling parent company. Deng, Zeng and He (2006) also confirmed that in 1999-2003, about $71.1 \%$ of controlling shareholders appointed their own people as the chairman of their controlled listed companies.

What are the motives behind controlling shareholders' violation of CSRC's regulations? Possible explanation might include, on the one hand, controlling shareholders need to strengthen their control over listed companies to maximize their interests in these companies (Zou, 2004); on the other hand, many SOEs become listed by means of "partition and package", which makes the assets of both listed companies and controlling shareholders incomplete. Therefore, these listed companies become more dependent on their controlling parent company, justifying the control over these listed companies exerted by their controlling shareholders. Then one might naturally ask, what determines controlling shareholders' tunneling behavior? What causes the asset incompleteness of both controlling shareholders and controlled listed companies? We assume that both answers have a lot to do with these listed companies' shareholding reform.

A majority of China's listed companies originate in restructured SOEs. During the course of shareholding reform, the government (especially governments at various local levels) might choose two shareholding reform modes, namely incomplete and complete restructuring modes. The incomplete restructuring mode refers to the so-called "partition and package" way of listing, in which the government (especially local governments) separates the high quality assets from a SOE and set up a new company to go public, while the non-performing assets and surplus employees are retained in the controlling parent company (controlling shareholder). In contrast, the complete restructuring mode refers to a 
"more holistic way of listing."1 The advantages of complete restructuring mode are obvious: no existence of controlling parent company, but relatively complete assets and business system, and a smaller burden for controlling shareholders etc. By comparison, firms become listed by means of the incomplete mode are likely to damage their former value chain, with incomplete assets for both the newly-listed company and its controlling parent company as many existing problems are simply "peeled off" from the "new" company and "transferred" to the controlling parent company. Lin et al. $(1999,2004)$ thus argued that SOEs carry too much policy burden. Therefore, the "incomplete restructuring mode" makes the problem-ridden controlling shareholders strongly motivated to strengthen their control over their "listed child companies" to solve their own problems. On the contrary, under the "complete restructuring mode," the business of both the controlling company and listed company remains rather intact and independent. The economic or policy burden of the controlling shareholders is also much smaller. Accordingly, controlling shareholders under the complete restructuring mode might have a smaller motive to tunnel their controlled listed companies.

As discussed above, the asset completeness and controlling shareholder's burden vary with different restructuring modes in the shareholding reform of SOEs. As a result, controlling shareholders in the incomplete restructuring mode might have stronger motivation to control and tunnel the listed companies under their control.

The rest of this article is organized as follows: Section 2 defines the mode of shareholding reform and degree of company control; Section 3 presents an empirical analysis, in which we firstly explore the factors influencing controlling shareholders' control over listed companies. We then analyze the relationship among restructuring modes, degree of company control, related trading and tunneling activities. Conclusions and implications are offered in the last section.

\section{Shareholding Reform Modes and Definition of the Degree of Company Control}

\subsection{Shareholding Reform Modes}

Generally speaking, shareholding reform modes can be divided into many subtypes, such as "renewal of the formal SOEs," "integration and restructuring," "partition and restructuring," "overall restructuring," "parallel restructuring,"

\footnotetext{
${ }^{1}$ For example, "holistic listing of a company" is one of the very important forms of SOE restructuring.
} 
"cascade restructuring", "peel-off," "split-up," and "converged restructuring," etc., to name just a few. ${ }^{2}$ In this article, according to the specific way government partitions and reorganizes SOE assets, debts and businesses, we categorize shareholding reform into four basic modes, namely overall restructuring, disbandment split-up, peel-off, and multi-reorganization.

"Overall restructuring" refers to that a SOE is reorganized into a new firm without conducting asset stripping or writing off debts. After the establishment of the new company, the former SOE ceases to exist. Companies that became listed by adopting the "overall restructuring" way are mostly firms in possession of quality assets, fewer historic burdens or fewer present policy burdens.

"Split-up" refers to SOEs peel off, under the requirement of regulatory bodies, non-operational assets, part or all operational assets unrelated to their main business, and debts. Assets and debts partitioned are transferred into a newly-established enterprise which is independent of the old SOE. The government then restructures the old SOE into a new shareholding firm. In so doing, SOEs become listed by means of peeling off bad assets are free of non-operational asset and surplus employees. However, the government might bear more direct expenses when SOEs adopt this way of restructuring. "Peel-off" refers to that a company separates part of its businesses and assets, and transfers them into a newly-established company, while other businesses and assets remain in the "old" company. Under most circumstances, the "old" company becomes the controlling parent company of the new company. By doing so, government controls many new companies and issue shares publicly in these new companies' name. "Multi-reorganization" refers to that the government transfers part of assets of several SOEs into one newly-established company. In some extreme cases, several SOEs inject all of their assets into the new company.

Usually, under the restructuring mode of "peel-off," part of the parent company's quality assets or certain production processes are taken out of the whole production process, are transferred from the "old SOE" into the new company. Similarly, under the mode of "multi-reorganization," many unrelated businesses or assets might be injected into one newly-established company. Both modes lead to asset incompleteness in both new and old companies. Meanwhile, under both modes, many non-performing, non-operational assets and surplus employee are transferred into the controlling parent company, constituting a heavy burden for the latter. In contrast, under the restructuring modes of "overall restructuring" and "split-up," the asset and business scope of both new and old companies remain rather complete. In addition, the controlling parent company also carries less heavy burden than in the first two modes. Based on the degree of

${ }^{2}$ For example, Wang (2004) divided the restructuring mode of SOEs into three types, namely overall restructuring, independent restructuring and convergent restructuring. 
restructuring, we therefore divide SOE restructuring into two groups, namely complete restructuring mode (i.e., overall restructuring and split up) and incomplete restructuring mode (i.e., peel-off and multi-reorganization).

\subsection{Degree of Control}

When measuring the independence of the board of directors and the degree of company control, domestic researchers mainly start from the perspective of Chairman/CEO duality (Wu, Bo and Xi, 1998; Li and Lai, 2004). However, we argue that in China's present institutional environment, it is more appropriate to use the cross appointment between the controlling shareholder firm and the listed firm to reflect the motive and degree of control by controlling shareholders over listed companies.

This article divides the control mode into three types. The first type is "complete control," in which a controlling shareholder appoints one of his men to hold concurrently the positions of CEO and chairman in a controlled listed company. The second type is called "incomplete control," in which the chairman rather than CEO in a controlled listed company is appointed by the controlling shareholder. The third type is called "complete separation," in which a controlling shareholder appoints neither CEO nor chairman in the controlled listed companies. ${ }^{3}$ Based on relevant study on the control structure of the board of directors of listed companies (Li, 2005; Zou and Chen, 2004), the first type of control has the highest degree of control, second highest with the second type, and the third type has the lowest degree of control.

We also take into consideration controlling shareholders' control over the board of supervisors. Even though CSRC issued in December 2001 the Standard No.2 on the Contents and Format of Information Disclosure Regarding Companies Issuing Securities to the Public, requiring listed companies to disclose the positions of their supervisors in their controlling shareholders' companies, such a disclosure was not complete until after 2002. As the time framework of this study is from 1998-2003, we are unable to collect complete data on supervisors of listed companies. Therefore, we choose the percentage of "unpaid" supervisors (i.e., supervisors receive no compensation from the controlled listed company they serve, but draw income from the controlling parent company or other related firms) to the total number of supervisors in a listed company as an indicator of controlling shareholder's control over the board because most of these "unpaid" supervisors are very likely to hold certain posts in controlling parent company. As most of China's listed companies are dominated by one single controlling shareholder, the above percentage can be used as a good proxy for controlling shareholder's control over listed companies.

\footnotetext{
${ }^{3}$ Seldom does a controlling shareholder send its own man to hold the position of CEO in controlled listed company but spare the post of chairman.
} 


\section{Empirical Tests}

\subsection{Data}

We collected 3-year data of 285 SOEs after their IPO between the end of 1997 and the end of 2000. Main data sources include sample companies' open prospectuses, listing particulars, annual reports, official websites and the CSMAR databank.

As shown in Table 1, about two thirds listed companies adopt the incomplete control mode, only a small fraction of them adopts the complete control mode. Because CSRC only requires that the CEO (rather than the chairman) of a listed company must not hold concurrently any posts in the controlling parent company, most of the controlling shareholders choose to appoint the chairman in listed companies. As a rule, the appointed chairman tends not to hold posts of CEO concurrently.

Table 1 Changes in the Degree of Control over Listed Companies in the First Three Years after IPO

\begin{tabular}{lcccc}
\hline & First year after & Second year after & Third year after & \multirow{2}{*}{ Total } \\
& IPO & IPO & IPO & \\
\hline \multirow{2}{*}{ Complete separation } & 74 & 80 & 80 & 234 \\
& $(27.9 \%)$ & $(29.3 \%)$ & $(28.9 \%)$ & $(28.7 \%)$ \\
Incomplete control & 172 & 178 & 185 & 535 \\
& $(64.9 \%)$ & $(65.2 \%)$ & $(66.8 \%)$ & $(65.6 \%)$ \\
Complete control & 19 & 15 & 12 & 46 \\
& $(7.2 \%)$ & $(5.5 \%)$ & $(4.3 \%)$ & $(5.6 \%)$ \\
Unpaid supervisors & 1.88 & 1.75 & 1.75 & 1.79 \\
& $(40.5 \%)$ & $(38.7 \%)$ & $(39.1 \%)$ & $(39.4 \%)$ \\
\hline
\end{tabular}

Note: Numbers in brackets are the ratio of specific sample size to the population.

We find the percentage of companies adopting the complete separation mode does not change significantly three years after IPO, while the percentage of companies adopting the incomplete control mode rise to a certain degree, and the percentage of companies adopting the complete control mode drop to a certain degree. These facts imply that, with the perfection of supervision mechanism in China's security market, some controlling shareholders cease to hold post of $\mathrm{CEO}$ to meet the requirement of CSRC. In comparison with the first year after IPO, the number and the ratio of "unpaid" supervisors to the total number of supervisors on board dropped to a certain degree in the second year after IPO. However, the two numbers remain unchanged afterwards.

3.2 Factors Influencing the Degree of Control over Listed Companies

\subsubsection{Single-Factor Analysis}

Besides different modes of restructuring, there might be other factors influencing 
the degree of control exerted by controlling shareholders over listed companies.

(1) Ownership structure. As a rule, when a certain shareholder has absolute control over a listed company, he/she are very likely to be successful in appointing chairman $(\mathrm{Li}, 2005)$. He (2003) found that $87 \%$ of the chairman of listed companies were nominated (and successfully selected) by their controlling shareholders. Zhou and Chen (2004) confirmed that there is a positive relationship between the ratio of shares held by the biggest shareholder and the probability of CEO/chairman duality. Li and Wang (2005) found a negative relationship between the percentage of shares held by the first biggest shareholder and the governance performance of the board of supervisors. He (2003) pointed out that it is in the best interests of controlling shareholders' to appoint their own supervisors to controlled listed companies. However, such a manipulation of the board of supervisors always fails due to resistance from other shareholders.

(2) Foreign-owned equity. Compared with domestic investors, foreign investors tend to be more mature and experienced, thus able to provide more rigorous supervision over listed companies, leading to more reasonable governance structure. Chhibber and Majumar (1999) found a positive relationship between foreign-owned equity and company performance. Major (1999) found evidence showing that the performance of foreign-owned enterprises tend to be better than that of private or state-owned enterprises. Chen and Jiang (2000) confirmed that the existence of B-shares is beneficial for the OPE improvement. Therefore, we assume that there is a positive relationship between foreign-owned equity and a company's governance efficiency.

(3) Government supervision. Generally speaking, state shareholders might control more rigorously listed companies in industries that have a vital bearing on the national economy and people's well being.

(4) Age of chairman. When the chairman of a controlling parent company is also the chairman of a controlled listed company and is approaching retirement, he/she is always required by relevant supervisory body to resign from one of these chairman posts to guarantee a smooth transfer of power. Sun et al. (2001) found that being the chairman of a listed company can bring one great prestige and honor. Meanwhile, being the chairman of a listed company is also likely to bring one more personal interest. Therefore, when facing the dilemma of either resigning the chairman post from the controlling parent company or from the controlled listed company, one is more likely to resign the first post. Consequently, the elder the age of its chairman, the more likely a listed company is to adopt the "complete separation mode."

(5) Growth. Lehn, Patro and Zhao (2003) argued that fast-growing enterprises need an efficient governance mechanism. Therefore, fast-growing enterprises tend to choose the mode of CEO duality to quicken decision making process. As 
data show that CEO duality mainly exist among "complete separation" companies, we argue that fast-growing enterprises are more likely to choose the "complete separation mode."

(6) Company size. As a rule, it is more difficult to run and control a company big in size. However, to meet the requirements of CSRC and built good company image, big companies are more likely to pay more attention to corporate governance. Therefore, there will be less people holding concurrently senior posts in both controlling company and controlled listed companies.

(7) Debt ratio. The higher a listed company's debt ratio, the higher its financial risks, and the more likely its controlling shareholders are to strengthen their control over the company.

As shown in Table 2, a majority of completely-restructured companies choose the "complete separation mode" (51.2\%), and incompletely-restructured companies the "incomplete control mode" (71.8\%). The percentage of incompletely-restructured company choosing "complete control mode" is higher than that of completely-restructured companies. Meanwhile, the percentage of unpaid supervisors in completely-restructured company is significantly lower than that of in incompletely-restructured company. All these facts show that the controlling shareholders of incompletely-restructured companies are more inclined to choose modes with higher degree of control.

In Table 2, most of the "equity-restricting" companies choose the "complete separation mode" (49.2\%), while the "non-equity-restricting" companies choose the "incomplete control mode" (68.9\%). In addition, the percentage of "non-equity-restricting" companies choosing "complete control mode" is higher than that of "equity-restricting" companies. However, the number and percentage of "unpaid" supervisors in "equity-restricting" companies are also higher than that of in "non-equity-restricting" companies.

The percentage of companies with no foreign equity choosing "incomplete control mode" is higher than that of companies with foreign equity. However, the percentage of the former choosing the "complete control mode" is smaller than that of the latter. Meanwhile, there are no significant difference of the number and percentage of "unpaid" supervisors in the two, showing that the existence of foreign equity does not significantly affect a company's choice of control mode.

As above, more than $80 \%$ companies under government supervision adopt the "incomplete control mode," while only $63.3 \%$ companies not under government control" modes. As demonstrated in Table 3, the percentage of shares held by controlling shareholders in "incomplete and complete control" companies are significantly higher than that of "complete separation" companies. However, we find no significant difference in the percentage of shares held by controlling shareholders between "complete control" and "incomplete control" companies. 
Table 2 Descriptive Statistics of Variables

\begin{tabular}{|c|c|c|c|c|c|c|}
\hline \multirow{2}{*}{ Samples } & \multicolumn{4}{|c|}{$\begin{array}{c}\text { Control both board of directors and the } \\
\text { managerial team }\end{array}$} & \multicolumn{2}{|c|}{$\begin{array}{l}\text { Control the board of } \\
\text { supervisors }\end{array}$} \\
\hline & Item & $\begin{array}{l}\text { Complete } \\
\text { separation }\end{array}$ & $\begin{array}{l}\text { Incomplete } \\
\text { control }\end{array}$ & $\begin{array}{l}\text { Complete } \\
\text { control }\end{array}$ & Item & $\begin{array}{l}\text { Unpaid } \\
\text { supervisors }\end{array}$ \\
\hline $\begin{array}{l}\text { Complete } \\
\text { restructuring }\end{array}$ & $\begin{array}{l}\text { Sample } \\
\text { size }\end{array}$ & $\begin{array}{c}105 \\
(51.2 \%)\end{array}$ & $\begin{array}{c}97 \\
(47.3 \%)\end{array}$ & $\begin{array}{l}3 \\
(1.5 \%)\end{array}$ & $\begin{array}{l}\text { Number of } \\
\text { supervisors }\end{array}$ & $\begin{array}{c}1.36^{* * *} \\
\left(30.11 \%^{* * *}\right)\end{array}$ \\
\hline $\begin{array}{l}\text { Incomplete } \\
\text { restructuring }\end{array}$ & $\begin{array}{l}\text { Sample } \\
\text { size }\end{array}$ & $\begin{array}{c}129 \\
(21.1 \%)\end{array}$ & $\begin{array}{c}438 \\
(71.8 \%)\end{array}$ & $\begin{array}{c}43 \\
(7.1 \%)\end{array}$ & $\begin{array}{l}\text { Number of } \\
\text { supervisors }\end{array}$ & $\begin{array}{c}1.94 \\
(42.5 \%)\end{array}$ \\
\hline $\begin{array}{l}\text { Equity } \\
\text { restriction }\end{array}$ & $\begin{array}{l}\text { Sample } \\
\text { size }\end{array}$ & $\begin{array}{c}59 \\
(49.2 \%)\end{array}$ & $\begin{array}{c}56 \\
(46.7 \%)\end{array}$ & $\begin{array}{c}5 \\
(4.2 \%)\end{array}$ & $\begin{array}{l}\text { Number of } \\
\text { supervisors }\end{array}$ & $\begin{array}{c}2.03^{*} \\
(43.7 \%)\end{array}$ \\
\hline $\begin{array}{l}\text { No equity } \\
\text { restriction }\end{array}$ & $\begin{array}{l}\text { Sample } \\
\text { size }\end{array}$ & $\begin{array}{c}175 \\
(25.2 \%)\end{array}$ & $\begin{array}{c}479 \\
(68.9 \%)\end{array}$ & $\begin{array}{c}41 \\
(5.9 \%)\end{array}$ & $\begin{array}{l}\text { Number of } \\
\text { supervisors }\end{array}$ & $\begin{array}{c}1.75 \\
(38.7 \%)\end{array}$ \\
\hline Foreign equity & $\begin{array}{l}\text { Sample } \\
\text { size }\end{array}$ & $\begin{array}{c}16 \\
(34.1 \%)\end{array}$ & $\begin{array}{c}27 \\
(57.4 \%)\end{array}$ & $\begin{array}{c}4 \\
(8.5 \%)\end{array}$ & $\begin{array}{l}\text { Number of } \\
\text { supervisors }\end{array}$ & $\begin{array}{c}1.88 \\
(40.7 \%)\end{array}$ \\
\hline $\begin{array}{l}\text { No foreign } \\
\text { equity }\end{array}$ & $\begin{array}{l}\text { Sample } \\
\text { size }\end{array}$ & $\begin{array}{c}218 \\
(28.4 \%)\end{array}$ & $\begin{array}{c}508 \\
(66.1 \%)\end{array}$ & $\begin{array}{c}42 \\
(5.5 \%)\end{array}$ & $\begin{array}{l}\text { Number of } \\
\text { supervisors }\end{array}$ & $\begin{array}{c}1.79 \\
(39.6 \%)\end{array}$ \\
\hline $\begin{array}{l}\text { Government } \\
\text { supervision }\end{array}$ & $\begin{array}{l}\text { Sample } \\
\text { size }\end{array}$ & $\begin{array}{c}15 \\
(14.3 \%)\end{array}$ & $\begin{array}{c}86 \\
(81.9 \%)\end{array}$ & $\begin{array}{c}4 \\
(3.8 \%)\end{array}$ & $\begin{array}{l}\text { Number of } \\
\text { supervisors }\end{array}$ & $\begin{array}{c}2.07^{*} \\
(43.2 \%)\end{array}$ \\
\hline $\begin{array}{l}\text { No government } \\
\text { supervision }\end{array}$ & $\begin{array}{l}\text { Sample } \\
\text { size }\end{array}$ & $\begin{array}{c}219 \\
(30.8 \%)\end{array}$ & $\begin{array}{c}449 \\
(63.3 \%)\end{array}$ & $\begin{array}{c}42 \\
(5.9 \%)\end{array}$ & $\begin{array}{l}\text { Number of } \\
\text { supervisors }\end{array}$ & $\begin{array}{c}1.75 \\
(38.8 \%)\end{array}$ \\
\hline $\begin{array}{l}\text { Percentage of } \\
\text { shares held } \\
\text { by the } \\
\text { controlling } \\
\text { shareholder }\end{array}$ & Mean & 0.437 & 0.561 & 0.532 & & \\
\hline Growth & Mean & 0.241 & 0.19 & 0.205 & & \\
\hline $\begin{array}{l}\text { Age of } \\
\text { chairman }\end{array}$ & Mean & 3.89 & 3.92 & 3.9 & & \\
\hline Company size & Mean & 19.89 & 20.38 & 20.2 & & \\
\hline Debt ratio & Mean & 0.403 & 0.412 & 0.424 & & \\
\hline
\end{tabular}

Note: 1 . Equity restriction refers to the difference between the percentage of shares held by the biggest shareholder and the total percentage of shares held by the No. 2 to No. 10 biggest shareholders is smaller than 0 . No equity restriction otherwise.

2. Government supervision refers to a company comes from industries under strict government supervision, including the mining, petroleum processing, smelting and pressing of ferrous metals, smelting and pressing of non-ferrous metals, electric power, gas, water supply, and telecommunication industries, and no government supervision otherwise.

3. Growth is measured with the grow rate of a sample company's sales revenue.

4. The age of chairman is the natural logarithm of the actual age of chairman.

5. Company size is the natural logarithm of the actual sales revenues of a company.

6. Debt ratio equals a company's total debt divided by total assets.

7. Numbers in brackets are the ratio of specific sample size to the population.

8. $* * *$ and * represent significant at 0.01 and 0.1 level, respectively. 
Table 3 Difference Testing of Variables

\begin{tabular}{lccc}
\hline & $\begin{array}{c}\text { Complete separation and } \\
\text { incomplete control }\end{array}$ & $\begin{array}{c}\text { Complete separation } \\
\text { and complete control }\end{array}$ & $\begin{array}{c}\text { Incomplete and } \\
\text { complete control }\end{array}$ \\
\hline $\begin{array}{l}\text { Equity of } \\
\text { controlling } \\
\text { shareholder(s) }\end{array}$ & $9.662^{* * *}$ & $3.533^{* * *}$ & 1.266 \\
Growth & $1.667^{*}$ & 0.473 & 0.226 \\
Age of chairman & $2.830^{* * *}$ & 0.324 & 0.899 \\
Company size & $6.887^{* * *}$ & $1.736^{*}$ & 1.331 \\
Debt ratio & 0.816 & 0.845 & 0.226 \\
\hline
\end{tabular}

Note: Numbers are the $T$ value. ${ }^{* * *}$ and $*$ refer to significant at 0.01 and 0.1 level, respectively.

Fast-growing companies are more likely to adopt the "complete separation mode." We find that the growth capability of companies adopting the "complete separation mode" is significantly higher than that of companies adopting "incomplete control mode," but not significantly different from that of companies adopting the "complete control mode." In addition, there is no significant difference in growth capability between companies adopting the "complete control mode" and companies adopting the "incomplete control mode."

The age of chairman in companies adopting the "incomplete control mode" is significantly older than that of companies adopting the "complete separation mode." However, there is no significant difference in this item between companies adopting the "incomplete control mode" and companies adopting the "complete control mode," and between the "incomplete control mode" and the "complete separation mode" (as shown in Table 2 and Table 3).

Big companies are more likely to adopt the modes of "incomplete control" and "complete control." However, there is no significant difference in terms of company size between companies adopting the "completely control mode" and "incomplete control mode." In addition, in terms of debt ratio, there is no significant difference among the three types of company control modes, as shown in Table 2 and 3.

\subsubsection{Multivariate Analysis}

First of all, by adopting the ordered choice model, we analyze the factors influencing controlling shareholders' control over the board of directors and managerial team. Definitions of relevant variables are presented in Table 4. The dependent variables $(C L D)$ of Model 1 to 5 in Table 5 represent the above three modes of controlling shareholders' control over listed companies, namely complete separation, incomplete control, complete control, indicated by 0,1 , and 2 , respectively. 
Table 4 Variable Definitions

\begin{tabular}{|c|c|c|}
\hline Abbreviation & Item & Definition \\
\hline$C L D$ & $\begin{array}{l}\text { Degree of control over the } \\
\text { board of supervisors and } \\
\text { CEO }\end{array}$ & $\begin{array}{l}\text { Complete separation mode }=0 \\
\text { Incomplete control mode }=1 \\
\text { Complete control mode }=2\end{array}$ \\
\hline$J S$ & $\begin{array}{l}\text { Percentage of "unpaid" } \\
\text { supervisors }\end{array}$ & $\begin{array}{l}\text { The number of "unpaid" supervisors to the total } \\
\text { number of supervisors on board }\end{array}$ \\
\hline RES & Restructuring mode & $\begin{array}{l}\text { Incomplete restructuring of } \mathrm{SOE}=1 \text {, and } 0 \\
\text { otherwise }\end{array}$ \\
\hline$L S$ & $\begin{array}{l}\text { Percentage of shares held } \\
\text { by controlling shareholder }\end{array}$ & $\begin{array}{l}\text { Total number of shares issued divided by total } \\
\text { number of shares held by the controlling } \\
\text { shareholders }\end{array}$ \\
\hline$O B$ & Balance of power & $\begin{array}{l}\text { It equals } 1 \text { if the difference of the shares held by } \\
\text { the biggest controlling shareholder and total } \\
\text { shares held by the second to the } 10^{\text {th }} \text { biggest } \\
\text { shareholder is smaller than } 1 \text {, and } 0 \text { otherwise }\end{array}$ \\
\hline$F S$ & Foreign shares & $\begin{array}{l}\text { It equals } 1 \text { if there are foreign-held shares in a } \\
\text { company, and } 0 \text { otherwise }\end{array}$ \\
\hline$A G E$ & Age of chairman & Natural logarithm of the age of chairman \\
\hline GOV & Government supervision & $\begin{array}{l}\text { It equals } 1 \text { when a company is from the mining, } \\
\text { petroleum processing, smelting and pressing of } \\
\text { ferrous metals, smelting and pressing of } \\
\text { non-ferrous metals, electric power, gas, water } \\
\text { supply, and telecommunication industry, and } 0 \\
\text { otherwise }\end{array}$ \\
\hline$G S D$ & Growth & Increase rate of a company's sales revenue. \\
\hline SIZE & Company size & Natural logarithm of a company's sales revenue. \\
\hline$D E B T$ & Debt ratio & Total debts divided by total assets \\
\hline$Y E A R$ & Year & Dummy variable of year \\
\hline
\end{tabular}

Second, we use the Tobin model to explore the influencing factors of "unpaid" supervisors in listed companies. Value 0 is used to stand for companies with no "unpaid" supervisors. Considering OLS regression is likely to bring forth biased and inconsistent estimate values, we use Tobit model to obtain better fitness. The independent variable $(J S)$ of Model 6 in Table 5 presents the ratio of "unpaid" supervisors to the total number of supervisors in a listed company.

As Model 1 in Table 5 shown, the coefficient of RES is significantly positive, indicating that the controlling shareholders of incompletely-restructured companies are more likely to control tightly listed companies. The coefficient of $L S$ in Model 2 is also significantly positive, showing that the more shares held by a controlling shareholder, the more likely it is to choose to control tightly listed company. The coefficient of $O B$ in Model 3 is significantly negative, showing that when strong counter force exits in a listed company, controlling shareholder 
Table 5 Factors Influencing the Degree of Control over Listed Companies

\begin{tabular}{lcccccc}
\hline & $\begin{array}{c}\text { Model 1 } \\
(C L D)\end{array}$ & $\begin{array}{c}\text { Model 2 } \\
(C L D)\end{array}$ & $\begin{array}{c}\text { Model 3 } \\
(C L D)\end{array}$ & $\begin{array}{c}\text { Model 4 } \\
(C L D)\end{array}$ & $\begin{array}{c}\text { Model 5 } \\
(C L D)\end{array}$ & $\begin{array}{c}\text { Model 6 } \\
(J S)\end{array}$ \\
\hline RES & $0.81^{* * *}$ & & & & $0.704^{* * *}$ & $0.185^{* * *}$ \\
& $(7.621)$ & & & & $(6.384)$ & $(4.855)$ \\
LS & & $1.7^{* * *}$ & & $1.596^{* * *}$ & $1.003^{* *}$ & -0.04 \\
& & $(5.524)$ & & $(4.324)$ & $(2.602)$ & $(-0.272)$ \\
OB & & & $-0.43^{* * *}$ & -0.04 & -0.06 & $0.122^{* *}$ \\
& & & $(-3.456)$ & $(-0.238)$ & $(-0.421)$ & $(2.233)$ \\
FS & 0.001 & 0.1 & -0.138 & 0.1 & 0.148 & 0.01 \\
& $(0.04)$ & $(0.524)$ & $(-0.757)$ & $(0.513)$ & $(0.784)$ & $(0.177)$ \\
AGE & -0.347 & -0.06 & 0.02 & -0.06 & -0.41 & \\
& $(-1.136)$ & $(-0.192)$ & $(0.07)$ & $(-0.2)$ & $(-1.33)$ & \\
GOV & 0.01 & -0.01 & 0.09 & -0.01 & -0.04 & 0.05 \\
& $(0.09)$ & $(-0.08)$ & $(0.685)$ & $(-0.05)$ & $(-0.264)$ & $(1.089)$ \\
GSD & -0.05 & -0.034 & -0.125 & -0.04 & 0.01 & -0.01 \\
& $(-0.495)$ & $(-0.297)$ & $(-1.097)$ & $(-0.309)$ & $(0.05)$ & $(-0.234)$ \\
SIZE & $0.207^{* * *}$ & $0.11^{* *}$ & $0.185^{* * *}$ & $0.111^{* *}$ & $0.14^{* * *}$ & 0.004 \\
& $(4.454)$ & $(2.234)$ & $(3.949)$ & $(2.224)$ & $(2.722)$ & $(0.252)$ \\
DEBT & 0.154 & 0.192 & 0.112 & 0.19 & 0.203 & 0.08 \\
YEAR & $(0.532)$ & $(0.667)$ & $(0.392)$ & $(0.66)$ & $(0.695)$ & $(0.832)$ \\
Pseudo $R^{2} /$ & Yes & Yes & Yes & Yes & Yes & Yes \\
Adj. $R^{2}$ & 0.09 & 0.066 & 0.05 & 0.066 & 0.10 & 0.023 \\
Log & & & & & & \\
likelihood & -592.7 & -607.2 & -616.6 & -607.2 & -586.5 & -509.7 \\
Total samples & 815 & 815 & 815 & 815 & 815 & 785 \\
\hline & & & & & \\
\hline
\end{tabular}

Note: The results of year effect are not presented in the regression model.

$* * *, * *$, and $*$ stand for significant at $0.01,0.05$ and 0.1 level, respectively.

is likely to choose control mode with lower degree of control. When entering $L S$ and $O B$ into Model 4 simultaneously, the coefficient of $L S$ remains significantly positive, while the coefficient of $O B$ becomes insignificant. As compared with Model 2, the degree of fitness of Model 4 does not improve significantly, showing that the effect of the degree of equity balance on the choice of control mode is caused by the low percentage of shares held by controlling shareholder in a company characterized by equity balance.

In Model 5, after the introduction of the variable of "restructuring mode," the coefficients of RES and $L S$ become significantly positive. However, as compared with Model 4, the significance of the coefficient of $L S$ drops significantly (from 1.5960 to 1.0004 , a drop of about $40 \%$ ), indicating that restructuring mode affects ownership structure, which in turn affects the composition of the board of 
directors and managerial team. The reason behind this is that incomplete restructuring is likely to cause the phenomenon of "one dominant shareholder": when setting up a joint stock company by means of incomplete restructuring (especially by means of "peel-off"), ${ }^{4}$ most of the assets injected into the new company come from one investor, hence the forming of one dominant shareholder. On the contrary, under the mode of complete restructuring, most of the former shareholders become shareholders of the restructured listed company, leading to rather wider diversion of share ownership. Our results show that the average percentage of shares held by the biggest shareholder in incompletelyestructured companies is $55.5 \%$, which is significantly higher than that of in completely-restructured companies (40.9\%). The coefficient of SIZE is significantly positive, indicating that the bigger the size of a company, the more difficult it is to control the company, and the more likely controlling shareholder is to strengthen its control over the company.

In Model 6, a significant and positive RES shows that there is a higher percentage of "unpaid supervisors" in incompletely-restructured companies than that of in completely-structured companies. This fact shows, to a certain degree, that the controlling shareholder of incompletely-restructured company is more likely to control tightly the board of supervisors, which in turn lead to higher degree of control over a listed company.

\subsubsection{Analysis of Sensitivity}

As above, we divide sampled companies into three subtypes, namely complete separation, incomplete control, and complete control. In the following section, we further divide sampled companies into three groups and use the Logit Model to conduct pair analysis of the relationship between restructuring mode and control mode. Specifically, group 1 represents complete separation vs. incomplete control). It equals 1 when a company belongs to incomplete control mode, and 0 when belongs to complete separation mode. Group 2 represents complete separation vs. complete control. It equals 1 when a company belongs to complete control mode, and 0 when belongs to complete separation mode. Group 3 represents complete control vs. incomplete control. It equals 1 when a company belongs to complete control mode, and 0 when belongs to incomplete control mode. The definitions of the above variables are the same as in Table 5 .

All RESs in Table 6 are significantly positive, showing that the controlling shareholders in incompletely-restructured companies are more prone to choose mode with higher degree of control.

\footnotetext{
4 About $80.2 \%$ of incompletely-restructured companies got listed by means of "peel-off," while only $19.8 \%$ of incompletely-restructured companies got listed by means of "multieorganization."
} 
Table 6 Grouped Restructuring and Company Control Modes

\begin{tabular}{lccc}
\hline & $\begin{array}{c}\text { Model } 7 \\
\text { (complete separation vs. } \\
\text { incomplete control) }\end{array}$ & $\begin{array}{c}\text { Model } 8 \\
\text { (complete separation vs. } \\
\text { complete control) }\end{array}$ & $\begin{array}{c}\text { Model 9 } \\
\text { (complete control vs. } \\
\text { incomplete control) }\end{array}$ \\
\hline RES & $0.971^{* * *}$ & $2.69^{* * *}$ & $1.59^{* * *}$ \\
LS & $24.34)$ & $(16.15)$ & $(6.09)$ \\
& $2.843^{* * *}$ & 1.792 & 1.35 \\
OB & $(14.18)$ & $(1.079)$ & $(1.02)$ \\
& 0.205 & -0.741 & 0.372 \\
FS & $(0.511)$ & $(1.054)$ & $(0.356)$ \\
& 0.013 & 1.06 & 5.683 \\
AGE & $(0.001)$ & $(2.204)$ & $(0.653)$ \\
& -0.065 & $-2.444^{*}$ & 1.335 \\
GOV & $(0.01)$ & $(3.742)$ & $(1.372)$ \\
& 0.249 & -0.49 & 0.621 \\
GSD & $(0.611)$ & $(0.510)$ & $(1.121)$ \\
& -0.09 & 0.243 & -0.444 \\
SIZE & $(0.167)$ & $(0.497)$ & $(1.031)$ \\
& $0.43^{* * *}$ & 0.348 & 0.124 \\
DEBT & $(15.8)$ & $(2.215)$ & $(0.44)$ \\
YEAR & -0.04 & 1.912 & -0.612 \\
Nagelkerke $R^{2}$ & $(0.04)$ & $(2.378)$ & $(0.32)$ \\
Obs. & Yes & Yes & Yes \\
\hline Note: & 0.237 & 0.32 & 0.074 \\
& 769 & 280 & 581 \\
\hline
\end{tabular}

Note: The results of year effect are not presented in the regression model.

$* * *, * *$, and $*$ stand for significant at $0.01,0.05$ and 0.1 level, respectively.

3.3 Restructuring Mode, Degree of Control and Related Trading and Fund Embezzlement

We have already pointed out the two flaws of incomplete restructuring mode: On the one hand, it might cause incompleteness in the assets of both controlled listed company and controlling parent company, which will lead to frequent related trading between listed company and controlling shareholder. On the other hand, in the incomplete restructuring mode, a lot of non-performing, non-operational, and non-core assets and surplus employees are transferred to the controlling parent company. To ensure its own survival and development, the controlling parent company is prone to tunnel resources from the listed company. And in doing so, controlling shareholders have to strengthen its control over the board of directors, board of supervisors, and managerial team of the listed company.

It has been generally agreed that the more tightly the controlling shareholder's 
control over a listed company, the more serious the controlling shareholder's related trading and tunneling behaviors. However, as we have appointed out above, these related trading and tunneling behaviors might caused by different restructuring modes. As Xia and Fang (2005) pointed out that one shall pay more attention to the government behaviors and motives when studying Chinese companies' governance. Consistent with their view, we believe that different restructuring modes affect differently the degree of control over listed companies, which in turn affects the degree of related trading and control shareholder's tunneling behaviors.

Below, we are going to measure the degree of related trading and controlling shareholder's tunneling on the interest of controlled listed company from three aspects, namely related sales, related renting, and funds embezzlement. The first two are the most common forms of related trading between controlled listed company and controlling shareholder, which also make them the most frequently adopted means to tunnel listed companies. Embezzlement of funds refers to controlling shareholder's tunneling of listed company's resources. It is an important means and token of controlling shareholder's tunneling of listed company. ${ }^{5}$

A controlling shareholder (i.e., the controlling parent group, including controlling parent company and other controlled member companies) not only conducts related trading with its controlled listed company or embezzle the

\footnotetext{
${ }^{5}$ In the end of 2002, CRSC conducted a general survey on all 1175 listed companies. The results showed that about 676 controlling shareholders embezzled a total of 96.7 billion yuan from controlled listed companies. In 2003, the amount of funds embezzled by controlling shares dropped to 57.7 billion yuan. In 2004, the amount further dropped to 50.9 billion yuan. However, fund embezzlement behaviors still prevail among controlling shareholders, which seriously affect the survival and development of listed companies. Some listed companies were even tunneled empty by their controlling shareholders, such as the Monkey King, Daqing Lianyi, Xingfu Shiye, Jinan Qingji, etc. Statistics show that $70 \%$ of listed companies suffering loss in the previous two years were tunneled by their controlling shareholders. To eliminate the tunneling behaviors of controlling shareholders, regulatory bodies have issued a series of laws and regulations. For example, in Sep., 2003, CSRC and the State-owned Assets Supervision and Administration Commission jointly issued the Notice of China Securities Regulatory Commission and the State-Owned Assets Supervision and Administration Commission of the State Council Concerning Some Issues on Regulating the Funds between Listed Companies and Associated Parties and Listed Companies' Provision of Guaranty to Other Parties to further regulate the fund flow between listed companies and their respective controlling shareholders or other associated parties, effectively control the risks of listed companies in providing guaranty to any other party, protect the lawful rights and interests of investors. To strictly prohibit controlling shareholders from embezzling funds of listed companies, in November 2005, CSRC issued the Notice of the State Council on Approving and Forwarding the Opinions of China Securities Regulatory Commission on Improving the Quality of Listed Companies.
} 
latter's funds, but also does so through other companies controlled by it.

The degree of related sales refers to the percentage of sales revenue that a listed company obtained from sales made to its controlling parent company to its total sales revenue. The degree of related renting refers to whether a controlled listed company rents assets from controlling parent company.

In terms of funds embezzlement, the controlling parent company might embezzle the funds of controlled listed company, and vice versa. The former is mainly realized by means of accounts receivable and prepayment, while the latter is mainly realized by means of payment receivable, down payment and other accounts payable. In this paper we regard the total account payable of a controlled listed company to its controlling parent company as account payable, and the total account receivable of a controlling parent company from its controlled listed company as account receivable. The difference between account receivable and account payable is the net account receivable, representing total amount of fund of a listed company embezzled by its controlling parent company. We here use the ratio of a company's total net account receivable to its total assets to measure controlling parent company's embezzlement of the funds of controlled listed company.

\subsubsection{Single Factor Analysis}

As shown in Table 7, we find that incompletely-restructured companies are more

Table 7 Restructuring Mode, Degree of Control and Related Sales

\begin{tabular}{|c|c|c|c|c|c|c|}
\hline & & Obs. & Percentage & Mean & Median & $\begin{array}{c}\text { Total number } \\
\text { of firms }\end{array}$ \\
\hline \multirow{2}{*}{$\begin{array}{l}\text { Restructuring } \\
\text { mode }\end{array}$} & $\begin{array}{l}\text { Complete } \\
\text { restructuring }\end{array}$ & 71 & $34.6 \%$ & 0.03 & 0 & 205 \\
\hline & $\begin{array}{l}\text { Incomplete } \\
\text { restructuring }\end{array}$ & 363 & $59.5 \%$ & 0.095 & 0.01 & 610 \\
\hline \multirow{3}{*}{$\begin{array}{l}\text { Control over } \\
\text { the board of } \\
\text { directors and } \\
\text { managerial } \\
\text { team }\end{array}$} & $\begin{array}{l}\text { Complete } \\
\text { separation }\end{array}$ & 75 & $32.1 \%$ & 0.045 & 0 & 234 \\
\hline & $\begin{array}{l}\text { Incomplete } \\
\text { control }\end{array}$ & 328 & $61.3 \%$ & 0.092 & 0.01 & 535 \\
\hline & $\begin{array}{c}\text { Complete } \\
\text { control }\end{array}$ & 31 & $67.4 \%$ & 0.096 & 0.011 & 46 \\
\hline \multirow{2}{*}{$\begin{array}{l}\text { Control over } \\
\text { the board of } \\
\text { supervisors }\end{array}$} & High & 251 & $57.2 \%$ & 0.09 & 0.005 & 439 \\
\hline & Low & 168 & $48.5 \%$ & 0.06 & 0 & 346 \\
\hline
\end{tabular}

Note: Obs. here refers to the number of sample company get involved in related sales. Mean and median refer to corresponding degree of related sales, namely the percentage of the sales revenue of a listed company made to its controlling parent company to its total sales revenues. 
likely to perform related sales behaviors. Their degree of related sales is three times higher than the mean of completely-restructured companies. Difference testing on the median and mean indicates that the degree of related sales in incompletely-restructured companies is significantly higher than that of completely-restructured companies (as shown in Table 8). In addition, Table 9 shows that the percentage of related renting in incompletely-restructured companies is $44.8 \%$, which is significantly higher than that of in completelyrestructured companies (14.1\%). Findings in Table 10 show that incompletelyrestructured companies are more likely to perform tunneling behaviors (average funds embezzled accounting to $3.3 \%$ ), while there is few funds embezzlement behaviors among completely-restructured companies. As shown in Table 11, the results of difference testing on the median and mean of incompletely-restructured companies in terms of the degree of funds embezzlement are significantly higher than that of completely-restructured companies.

Table 8 Difference Testing of the Degree of Related Sales

\begin{tabular}{lccccc}
\hline & $\begin{array}{l}\text { Complete } \\
\text { restructuring } \\
\text { and incomplete } \\
\text { restructuring }\end{array}$ & $\begin{array}{l}\text { Complete } \\
\text { separation } \\
\text { incomplete } \\
\text { control }\end{array}$ & $\begin{array}{l}\text { Complete } \\
\text { separation and } \\
\text { complete } \\
\text { control }\end{array}$ & $\begin{array}{l}\text { Incomplete } \\
\text { control and } \\
\text { complete } \\
\text { control }\end{array}$ & $\begin{array}{l}\text { High and low } \\
\text { degree of } \\
\text { control over the } \\
\text { board of } \\
\text { directors }\end{array}$ \\
\hline Mean & $6.798^{* * *}$ & $4.109^{* * *}$ & $2.272^{* *}$ & 0.159 & $2.684^{* * *}$ \\
Median & $7.115^{* * *}$ & $7.088^{* * *}$ & $4.424^{* * *}$ & 0.574 & $2.971^{* * *}$
\end{tabular}

Note: Mean is obtained from $T$-test. Median is obtained from Mann-Whitney U test. *** and ** indicates significant at $1 \%$ and $5 \%$ level, respectively.

Table 9 Restructuring Mode, Degree of Control and Related Renting

\begin{tabular}{llrcc}
\hline & & Obs. & Percentage & Total number of firms \\
\hline $\begin{array}{l}\text { Restructuring } \\
\text { mode }\end{array}$ & Complete restructuring & 29 & $14.1 \%$ & 205 \\
& Incomplete restructuring & 273 & $44.8 \%$ & 610 \\
\hline $\begin{array}{l}\text { Control of the } \\
\text { board of directors }\end{array}$ & Complete restructuring & 60 & $25.6 \%$ & 234 \\
$\begin{array}{l}\text { and managerial } \\
\text { team }\end{array}$ & Incomplete control & 222 & $41.5 \%$ & 535 \\
\hline $\begin{array}{c}\text { Control of the } \\
\text { board of }\end{array}$ & Complete control & 20 & $43.5 \%$ & 46 \\
$\quad$ supervisors & Low & 174 & $39.6 \%$ & 439 \\
\hline
\end{tabular}

Note: Obs. here refers to the number of sample companies performed related renting to the total number of samples.

The above findings reveal that, as compared with completely-restructured companies, the controlling shareholders of incompletely-restructured companies 
have greater motivation to perform related trading or embezzle directly the funds of controlled listed companies. Accordingly, their degrees of related trading and fund embezzlement are also higher than that of completely-restructured companies.

Table 10 Restructuring Mode, Degree of Control and Fund Embezzlement

\begin{tabular}{lcccccc}
\hline & Obs. & Percentage & Mean & Median & $\begin{array}{c}\text { Total number } \\
\text { of firms }\end{array}$ \\
\hline $\begin{array}{c}\text { Restructuring } \\
\text { mode }\end{array}$ & $\begin{array}{c}\text { Complete } \\
\text { restructuring } \\
\text { Incomplete } \\
\text { restructuring }\end{array}$ & 62 & $30.2 \%$ & 0.001 & 0 & 205 \\
\hline $\begin{array}{c}\text { Complete } \\
\text { restructuring }\end{array}$ & 91 & $38.5 \%$ & 0.008 & 0 & 610 \\
$\begin{array}{c}\text { Control of the } \\
\text { board of } \\
\text { directors and } \\
\text { managerial } \\
\text { team }\end{array}$ & $\begin{array}{c}\text { Incomplete } \\
\text { control }\end{array}$ & 324 & $60.6 \%$ & 0.03 & 0.003 & 535 \\
\hline $\begin{array}{c}\text { Complete } \\
\text { control }\end{array}$ & 32 & $69.6 \%$ & 0.035 & 0.004 & 46 \\
\hline $\begin{array}{c}\text { bontrol of the } \\
\text { supervisors }\end{array}$ & High & 258 & $58.8 \%$ & 0.025 & 0.003 & 439 \\
\hline
\end{tabular}

Note: Obs. here refers to sample companies get involved into fund embezzlement. Mean and median represent the degree of fund embezzlement.

Table 11 Difference Testing of the Degree of Fund Embezzlement

\begin{tabular}{llllll}
\hline & $\begin{array}{l}\text { Complete } \\
\text { restructuring } \\
\text { and incomplete } \\
\text { restructuring }\end{array}$ & $\begin{array}{l}\text { Complete } \\
\text { separation and } \\
\text { incomplete } \\
\text { control }\end{array}$ & $\begin{array}{l}\text { Complete } \\
\text { separation } \\
\text { and complete } \\
\text { control }\end{array}$ & $\begin{array}{l}\text { Incomplete } \\
\text { control and } \\
\text { complete } \\
\text { control }\end{array}$ & $\begin{array}{l}\text { High and low } \\
\text { degree of } \\
\text { control over } \\
\text { the board of } \\
\text { directors }\end{array}$ \\
\hline Mean & $7.325^{* * *}$ & $4.855^{* * *}$ & $2.013^{* *}$ & 0.989 & 0.08 \\
Median & $6.357^{* * *}$ & $3.527^{* * *}$ & $2.846^{* * *}$ & 0.492 & $1.771^{*}$ \\
\hline
\end{tabular}

Note: Mean is obtained from $T$-test. Median is obtained from Mann-Whitney U test. *** and ** refers to significant at $1 \%$ and $5 \%$ level, respectively.

As shown in Table 7, 9 and 10, for the completely-separated companies, the percentages of related sales, related renting and fund embezzlement are $32.1 \%$, $25.6 \%$ and $38.5 \%$, respectively; for the incompletely-controlled samples, corresponding percentages are $61.3 \%, 41.5 \%$ and $60.6 \%$, respectively; for the completely-controlled, $67.4 \%, 43.5 \%$ and $69.6 \%$, respectively. These data show that listed companies characterized by higher degree of control over the board of directors and senior managers are more likely to perform related trading and funds embezzlement behaviors. In addition, as predicted in Table 8 and 11, the 
degrees of related trading and funds embezzlement in completely-controlled and incomplete-controlled companies are significantly higher than of in completely-separated companies, while these two degrees are slightly (yet insignificantly) higher in completely-controlled companies than that of in incompletely-restructured companies.

In the above five tables (Table 7-Table 11), we divide sample companies into two groups based on the degree of control over the board of supervisors. The first group has high degree of control over the board of supervisors (there is more than one "unpaid" supervisor on board); the second group has comparatively lower degree of control. In group one, the percentages of companies involved in related sales, related renting, and funds embezzlement are 57.2\%, 39.6\%, and $58.8 \%$, respectively, as compared with corresponding percentages in the second group $(48.5 \%, 34.4 \%$, and $50 \%$, respectively). Although the degree of control of group one is significantly higher than that of the second group in terms of related sales and funds embezzlement, there is no significance difference in the degree of funds embezzlement between the two groups.

\subsubsection{Multivariate Analysis}

In Table 12, the dependent variables for Model 10 and 13, Model 11 and 14, and Model 12 and 15 are the degree of funds embezzlement, degree of related sales and related renting, respectively. When a company performs related sales or renting, or embezzles funds, the value of corresponding variable equals 1 and 0 otherwise. Tobin model and logit model are used for Model 11 and 14 and Model 12 and 15 , respectively.

Without loading in RES, CLD and $J S$ are significantly positive in Model 10, 11, and 12 (except the JS in Model 10). However, after loading RES into Model 13, 14 and 15, most RESs become significantly positive, showing that the degree of fund embezzlement and related trading in incompletely restructured companies are higher than that of in completely restructured companies. More importantly, as compared with Models 10,11 and 12, the value and significance of $C L D$ and $J S$ drop considerably. For example, as compared with Model 10, the value of $C L D$ in Model 13 drops about 50\%; as compared with Model 11, the value of $C L D$ in Model 14 drops over 30\% and $J S$ becomes insignificant; as compared with Model 12, both $C L D$ and $J S$ become insignificant in Model 15.

The above findings show that the higher the degree of control over listed companies, the higher the degree of related trading and funds embezzlement. However, to a large degree, different degrees of control stems from different restructuring modes. In other words, restructuring modes affect greatly controlling shareholders' control over listed companies, which in turn influences related trading and funds embezzlement. Therefore, we argue that restructuring mode is the main determinant of related trading and funds embezzlement. 
Table 12 Restructuring Mode, Company Control, Related Trading and Fund Embezzlement

\begin{tabular}{lcccccc}
\hline & $\begin{array}{c}\text { Model 10 } \\
\text { (fund } \\
\text { embezzlement) }\end{array}$ & $\begin{array}{c}\text { Model 11 } \\
\text { (related } \\
\text { sales) }\end{array}$ & $\begin{array}{c}\text { Model 12 } \\
\text { (related } \\
\text { renting) }\end{array}$ & $\begin{array}{c}\text { Model 13 } \\
\text { (fund } \\
\text { embezzlement) }\end{array}$ & $\begin{array}{c}\text { Model 14 } \\
\text { (related } \\
\text { sales) }\end{array}$ & $\begin{array}{c}\text { Model 15 } \\
\text { (related } \\
\text { renting) }\end{array}$ \\
\hline Constant & 0.152 & -0.358 & -2.726 & 0.13 & -0.411 & $-3.481^{*}$ \\
CLD & $(1.162)$ & $(-1.002)$ & $(-1.286)$ & $(1.027)$ & $(-1.159)$ & $(-1.686)$ \\
& $0.02^{* * *}$ & $0.07^{* * *}$ & $0.356^{* *}$ & $0.01^{* *}$ & $0.048^{* * *}$ & 0.1195 \\
JS & $(3.376)$ & $(3.557)$ & $(2.386)$ & $(2.443)$ & $(2.645)$ & $(1.266)$ \\
& 0.0001 & $0.054^{*}$ & $0.455^{*}$ & -0.01 & 0.036 & 0.236 \\
RES & $(0.08)$ & $(1.692)$ & $(1.774)$ & $(-0.534)$ & $(1.105)$ & $(0.897)$ \\
& & & & $0.03^{* * *}$ & $0.1^{* * *}$ & $1.262^{* * *}$ \\
LS & & & & $(5.53)$ & $(3.611)$ & $(5.181)$ \\
& $(1.274)$ & $(3.712)$ & $(6.518)$ & $(-0.06)$ & $(2.788)$ & $(4.779)$ \\
FS & -0.01 & -0.03 & $0.684^{*}$ & -0.01 & -0.02 & $0.82^{* *}$ \\
& $(-1.342)$ & $(-0.808)$ & $(1.978)$ & $(-1.069)$ & $(-0.521)$ & $(2.319)$ \\
GOV & 0.001 & $0.08^{* * *}$ & 0.128 & -0.0001 & $0.08^{* *}$ & 0.06 \\
& $(0.15)$ & $(3.062)$ & $(0.531)$ & $(-0.01)$ & $(2.848)$ & $(0.261)$ \\
SIZE & $-0.01^{*}$ & 0.02 & -0.01 & -0.01 & 0.02 & 0.02 \\
& $(-1.759)$ & $(1.471)$ & $(-0.103)$ & $(-1.579)$ & $(1.606)$ & $(0.22)$ \\
DEBT & $0.08^{* * *}$ & 0.004 & -0.228 & $0.08^{* * *}$ & 0.01 & -0.212 \\
YEAR & $(2.704)$ & $(0.06)$ & $(-0.428)$ & $(2.751)$ & $(0.112)$ & $(-0.387)$ \\
Adj. $R^{2} /$ & Yes & Yes & Yes & Yes & Yes & Yes \\
Log & & & & & & \\
likelihood & 0.03 & 0.063 & -478.6 & 0.05 & 0.07 & -463.1 \\
Total obs. & 785 & 785 & 785 & 785 & 785 & 785 \\
\hline & & & & & &
\end{tabular}

\section{Main Conclusion and Implication}

In China, as cross appointment in listed companies prevails, many controlling shareholders realize their control over listed companies by means of assigning directors, CEOs, or supervisors to their controlled listed companies. By analyzing the post-IPO data of 285 SOEs in 1997-2000, we find that most controlling shareholders prefer incomplete control mode, and least prefer complete control mode. Specifically, over $70 \%$ of controlling parent companies appoint their own people to hold the post of chairman (or hold concurrently the post of CEO and chairman) in controlled listed companies. Meanwhile, there are about $40 \%$ of supervisors of listed companies do not receive compensation from the listed company they serve. After an in-depth analysis of the main determinant of the degree of control over listed companies, we find that different restructuring modes affect differentially controlling shareholders' control over 
listed companies. In addition, we also find that the greater the degree of control over listed companies, the more serious the related trading and tunneling problems.

The implication of this article is, to a large extent, controlling shareholders' attempt to control listed company is induced by incomplete restructuring of the former SOEs. Our findings have revealed that incomplete restructuring of former SOEs has influenced negatively the governance efficiency of these enterprises. The key to solve this problem is to eliminate the incomplete restructuring modes formerly adopted in SOE reform (such as split-up, peel-off, etc.) and implement proactively thorough and complete restructuring modes. As for the burden-ridden controlling parent companies of China's listed companies, government (especially local governments) shall take effective measures to reduce their policy burden and rationalize the relationship between the controlled listed companies and their state-owned parent company.

Acknowledgements This research is supported by the Program for New Century Excellent Talents in University of the Ministry of Education, and the National Natural Science Foundation of China (No. 70802011).

\section{References}

Chhibber P, Majumar S (1999). Foreign ownership and profitability: Property rights, control, and the performance of firms in Indian industry. The Journal of Law and Economics, 42: 209-238

Claessens S, Djankov S, Lang H P (2000). The separation of ownership and control in East Asian corporations. Journal of Financial Economics, 58: 81-112

Faccio M, Lang L H P (2002). The ultimate ownership of western European corporations. Journal of Financial Economics, 65: 365-395

Frydman R, Pistor K, Rapaczynski A (1996). Investing in insider-dominated firms: A study of Russian voucher privatization funds. In: Corporate Governance in Central Europe and Russia. London, New York: CEU Press

Frydman R, Rapaczynski A, Earle J S (1993). The Privatization Process in Europe Prague. Budapest: Central European University Press

La Porta R, Lopez-de-Silanes F, Shleifer A (1999). Corporate ownership around the world. Journal of Finance, 54: 471-517

Lehn K, Patro S, Zhao M (2003). Determinants of the size and structure of corporate boards: 1935-2000. Working paper

Major I (1999). The transforming enterprise: Company performance after privatization in Hungary between 1988 and 1997. Comparative Economic Studies, 61: 61-110

Schutte C (2000). Privatization and Corporate Control in the Czech Republic. Northampton: Edward Elgar

陈晓, 江东 (Chen Xiao, Jiang Dong) (2000). 股权多元化、公司业绩与行业竞争性 (The diversity of stock ownership, firm performance and industrial competition). 经济研究, (8): 28-37 
邓建平, 曾勇, 何佳 (Deng Jianping, Zeng Yong, He Jia) (2006). 改制模式影响董事会特征 吗? (Do restructuring models affect the characteristics of board of directors?) 会计研究, (11): $82-88$

冯舜华 (Feng Shunhua) (2003). 转轨经济中公司治理的模式问题: 从捷克共和国的公司 治理中得到的启示 (Corporate governance mode in transition from Czechic experience: Englightenment from corporate governance in the Czech Republic). 世界经济, (2): 3-10

何卫东 (He Weidong) (2003). 深交所上市公司治理调查分析报告 (An Investigation of Corporate Governance on Listed Companies in Shenzhen Stock Exchange). 深圳证券交易 所报告

黄速建 (Huang Sujian) (2004). 国有存续企业改革: 问题与建议 (Reform of state-owned survived enterprises: Problem and suggestion). 经济管理, (5): 9-16

李常青, 赖建清 (Li Changqing, Lai Jianqing) (2004). 董事会特征影响公司绩效吗? (Do the characteristics of board of directors affect firm's performance?) 金融研究, (5): 64-77

李东平 (Li Dongping) (2005). 大股东控制、盈余管理与上市公司业绩滑坡 (Large Shareholder Control, Earnings Management and Firm Performance Decrease). 北京: 中国 财政经济出版社

李维安, 王世权 (Li Wei'an; Wang Shiquan) (2005). 中国上市公司监事会治理绩效评价和 实证研究 (Appraisal and empirical research about the governance efficiency of supervisor board of China s public companies). 南开管理评论, (1): 4-9

林毅夫 (Lin Yifu) (2004). 自生能力与我国当前资本市场的建设 (Viability and the development of China's capital markets). 经济学(季刊), (2): 389-395

林毅夫, 蔡昉, 李周 (Lin Yifu, Cai Fang, Li Zhou) (1999). 中国的奇迹: 发展战略与经济 改革 (增订版) (Miracle of China: Development Strategy and Economic Reform (additional edition)). 上海: 上海三联书店和上海人民出版社

蒲自立, 刘苟佳 (Pu Zili, Liu Shaojia) (2004). 公司控制中的董事会领导结构和公司绩效 (The structure of leadership of board of directors and firm performance). 管理世界, (9): $117-130$

青木昌彦 (Aoki Masahiko) (1994). 对内部人控制的控制一一转轨经济中公司治理的若干 问题 (Controlling insider control in transition: Some issues on corporate governance in transition economy). 改革, (6): 11-24

宋德舜 (Song Deshun) (2004). 国有控股、最高决策者激励与公司绩效 (State holding, incentives of uppermost decision-maker and firm performance). 中国工业经济, (3): 91-98

孙铮, 姜秀华, 任强 (Sun Zheng, Jiang Xiuhua, Ren Qiang) (2001). 治理结构与公司业绩 的相关性研究 (A study on the correlation between governance structure and firm performance). 财经研究, (4): 3-12

田春生 (Tian Chunsheng) (2002). “内部人控制”与利益集团中国与俄罗斯公司治理结构的 一个实证分析 (A comparative empirical study on insider control and interest group of Chinese and Russian corporate). 经济社会体制改革比较, (5): 18-26

吴淑琨, 柏杰, 席西民 (Wu Shukun, Bo Jie, Xi Youmin) (1998). 董事长与总经理两职的分 离与合一 (The duality of CEO and chairman of the board). 经济研究, (8): 21-28

夏立军, 方轶强 (Xia Lijun, Fang Yiqiang) (2005). 政府控制、治理环境与公司价值一一来 自中国证券市场的经验证据 (Government control, institutional environment and firm value: Evidence from the Chinese securities market). 经济研究, (5): 40-51

邹风，陈晓 (Zou Feng, Chen Xiao) (2004a). 股权特征与董事会领导结构关系的实证研究 (An empirical study on the relationship between the ownership characteristics and the board leadership structure). 南开管理评论, (1): 49-56

邹风, 陈晓 (Zou Feng, Chen Xiao) (2004b). “三分开”政策对董事会结构影响的实证研究 (An empirical study on the effects of "San Fen Kai" policy on board composition and leadership). 经济学(季刊), (2): 425-437 